\title{
Gnosticizam i neopelagijanizam - zapreka svetosti ili izvor konfuzije?
}

Mikolaj Martinjak*

mika@ffrz.hr https://doi.org/10.31192/np.17.3.5

UDK: $27-874$

272-732.2Franciscus, papa

(093.2)

Pregledni članaka / Review Primljeno: 24. listopada 2019. Prihvaćeno: 3. studenog 2019.

Pojmovi gnosticizam i pelagijanizam poznati su teolozima, povjesničarima, religiolozima, filozofima i drugim istraživačima humanističkoga područja. Kao pojedinačne pojmove možemo ih od vremena do vremena čuti $i$ u kolokvijalnom govoru, posebice izvedenicu agnosticizam ili agnostik. Do pobudnica pape Franje ova dva pojma bila su vezana uz crkvene hereze s početaka života Crkve. Članak, u povijesni kontekst ove hereze smješta Papin govor o gnosticizmu i pelagijanizmu kojeg započinje svojom pobudnicom Evangelii gaudium, a proširuje ga u pobudnici Gaudete et exsultate. Nakon kratkog prikaza klasične uporabe ovih pojmova i problematike koja se uz njih veže, kao i Papine interpretacije ovih pojmova, članak odgovara na pitanje jesu li ovi pojmovi uistinu »zapreka« na putu svetosti ili izvor konfuzije.

Ključne riječi: crkvene hereze, gnosticizam, kršćanska antropologija, papa Franjo, pelagijanizam, pobudnica Evangelii gaudium, pobudnica Gaudete et exsualtate.

\footnotetext{
* Mr. sc. Mikolaj Martinjak, doktorand, Sveučilište u Zagrebu, Fakultet filozofije i religijskih znanosti; Jordanovac 110, HR-10000 Zagreb.
} 


\section{Uvod}

Iako je pobudnica pape Franje Gaudete et exsualtate objavljena prije nešto više od godinu dana (9. travnja 2018.), te svojim izlaskom nije imala isti odjek kao neke od pobudnica i enciklika prijašnjih papa, čini se da nažalost nije dovoljno istražena niti shvaćena. Papinsko sveučilište Gregorijana u Rimu prošle je godine započelo niz javnih konferencija pod nazivom »Ljudska svetost«, a koji se bavi tematikom pobudnice Gaudete et exsultate, što se nastavilo i u 2019. godini. ${ }^{1}$ Tako Andrea Grillo, jedan od predavača, svoje izlaganje započinje tumačenjem pojmova gnosticizam i pelagijanizam u nauku pape Franje, te ističe da Papa, koristeći ove pojmove, čini svojevrstan obrat kako bi mogao "protumačiti« njihovu tradiciju i iskoristiti ih za tumačenje novih sadržaja. ${ }^{2}$ Čini se da je najveći problem i izvor konfuzije govora pape Franje o gnosticizmu i pelagijanizmu upravo shvaćanje uloge tih termina. Većina interpreta Papine misli ističe da papa Franjo tim pojmovima ne zalazi u klasično tumačenje, nego ih koristi kao opis situacije u kojoj se svijet nalazi. Bez obzira na interpretaciju pojmova, čini se da i tu Papin govor nailazi na poteškoće, nerazumijevanje i neprihvaćanje, te da je izvor podjela i konfuzije unutar Crkve. Kritike koje su upućene papi Franji vezane su uz njegovo »samo-citiranje«, tj. da (kao referencu) koristi vlastite tekstove za tumačenje onoga što želi istaknuti ili izreći. Prijašnji pape su svoje tekstove i poslanice temeljili na dokumentima Crkve, te na otačkoj predaji i tradiciji. Kritičari smatraju da je papa Franjo više zauzet siromaštvom, migrantima i ostalim stvarima negoli dokumentima Crkve.

Gnosticizam i pelagijanizam su stari neprijatelji Crkve koji su kroz stoljeća blago tinjali, a ponekad i žarili unutar nje, ali i izvan nje same. Gnosticizam nije prestao postojati s crkvenim zakonima i odredbama, već je uvijek bio prisutan i imao svoje pristalice. Sam problem gnosticizma je star koliko i sama Crkva, dok je problem pelagijanizma nešto »mlađi«. Julien Ries u uvodnom dijelu svoje knjige Gli gnostici: storia e dottrina, podsjeća čitatelje da već 180. godine sveti Irenej, lionski biskup, piše Adversus haeresies i u njemu pobija protivnike prave, jedinstvene i istinske vjere. ${ }^{3}$ Osim Ireneja, protiv gnostika i gnosticizma Crkva u svojoj baštini ima i spise Hipolita Rimskoga, Tertulijana, Origena i ostalih

\footnotetext{
${ }^{1}$ Ciklus javnih konferencija »Ljudska svetost« koje promovira Centar za vjeru i kulturu »Albert Hurtado« Papinskoga gregorijanskog sveučilišta posvećen je apostolskom pozivu Gaudete et exsultate. Prvi sastanak održao se u utorak 6. studenog 2018., a govornik je bio benediktinski teolog Ghislain Lafont o temi Božje strpljivosti i primanja dara. Ciklus se nastavio u 2019. godini, a sudjelovali su teolozi i predavači: Luigi Ciotti, Sandro Barlone, Stefano Del Bove, Andrea Grillo, Alberto Melloni i Luciano Manicardi.

${ }^{2}$ Usp. Andrea GRILLO, Gnosticismo e pelagianesimo secondo papa Francesco: visione classica e lettura »capovolta« (14.04.2019), https://sites.google.com/site/ilgiornaledirodafa500/numero-500---14-aprile-2019/gnosticismo-e-pelagianesimo-secondo-papa-francesco-visione-classica-e-lettura-capovolta---andrea-grillo (05.09.2019).

${ }^{3}$ Julien RIES, Gli gnostici: storia e dottrina, Milano, Jaca Book, 2010, XXI.
} 
crkvenih otaca koji se bore za kršćanski identitet i čistoću nauka. ${ }^{4}$ Irenejeva misao, ali i ostali spisi hereziologa Crkve stoljećima su bili glavno oruđe za proučavanje i klasificiranje gnosticizma u Crkvi i izvan nje. No, upravo je Irenejev spis pomalo zaboravljen jer se od petoga stoljeća pa sve do pape Franje u Crkvi nitko izričito nije bavio gnosticizmom u smislu crkvene hijerarhije i korištenja pojmovlja u službenim dokumentima Crkve. Nijedan dokument, odredba ni deklaracija Drugoga vatikanskog koncila nijednom riječju ne spominje gnozu, gnosticizam ili gnostike, kao što ne spominje niti Pelagija ili pelagijanizam.

Gnosticizam je izvan Crkve i nakon službene osude imao svoje predstavnike i zagovornike, no svoju renesansu doživljava sredinom prošloga stoljeća otkrićem tekstova u Nag Hammadiju, 1945. godine. Time zapravo u znanstvenim krugovima ubrzano raste interes za gnosticizmom i gnosticima.

Razumijevanje pojmova gnoza i gnosticizam prolazi kroz svojevrsnu evoluciju značenja. ${ }^{5}$ Posljednjih tridesetak godina u znanstvenim krugovima znanstvenici nastoje obrazložiti što je to gnosticizam, što je gnoza, tko su gnostici i koje su njihove najbitnije karakteristike. ${ }^{6}$ Zlatko Pleše u svom članku »Gnostic literature « navodi da je moderna tipološka kategorizacija pojmova gnoza i gnosticizam pod neprestanim napadima jer pokušava apstraktne pojmove učiniti pristupačnijima i jasnijima kroz teološke pozicije koje se same u sebi razilaze. Osim pogrešne i čudne teologije, kategorizacija obuhvaća i etičke orijentacije pojedinaca kao i prikaze ritualnih praksi koje su često proturječne. ${ }^{7}$

${ }^{4}$ Usp. Antti MARJANEN, Gnosticism, u: Susan Ashbrook HARVEY; David G HUNTER (ur.), The Oxford handbook of early Christian studies, Oxford, Oxford University Press, 2010, 211.

${ }_{5}^{5}$ Ries iznosi različite pokušaje definiranja gnoze na francuskom i anglosaksonskim jezicima, te gnosticizma na francuskom, njemačkom i engleskom. Za kronološki prikaz evolucije pojmova iznosi definicije obaju pojmova u rječnicima, enciklopedijama i u pojedinih autora koji se smatraju zaslužnima za razvijanje nauke o gnozi i gnosticizmu (usp. Ries, Gli gnostici..., 2-6).

${ }^{6}$ U Mesinni (Italija) 1966. održan je jedan od prvih simpozija posvećenih gnosticizmu kao kategoriji gdje se raspravljalo o naravi i terminologiji. Williams iznosi kritiku pojmova i termina predlažući da se umjesto termina gnosticizma za pokret uzme drukčiji naslov, a njegov prijedlog je termin biblijski demijurgizam koji bi obuhvatio gnostičke misli koje u sebi imaju demijurološke koncepte (usp. Michael A. WILlIAMS, Rethinking 'Gnosticism.' An Argument For Dismantling A Dubious Category, Princeton, Princeton University Press, 1996).

7 »U suvremenim tipološkim pristupima gnosticizam je različito obilježen kao '(kršćansko) proširenje aleksandrijske filozofije religije, s radikalno dualističkim pogledom na svemir i čestom sklonošću alegorijskom tumačenju židovskog spisa' (F. C. BAUR, Die christliche Gnosis oder die christliche Religionsphilosophie in ihrer historischen Entwicklung, Tübingen, 1835.); nusprodukt 'akutne helenizacije kršćanstva' (A. v. HARNACK, Lehrbuch der Dogmengeschichte, sv. 1, Die Entstehung des christlichen Dogmas, Tübingen, 1909.); pretkršćansku religiju izvedenu iz orijentalnog mita primarnog čovjeka-otkupitelja (W. BOUSSET, Hauptprobleme der Gnosis. Forschung zur Religion und Literatur des Alten und Neuen Testaments, 10, Göttingen, 1907.); 'Najizvorniji izraz Daseinsverfassung', anti-kozmosa i 'prosvjedna egzegeza' u grčko-rimskoj religioznosti (H. JONAS, Gnosis und spatantiker Geist. I. Die mitologische Gnosis [FRLANT 63], Göttingen, 1964.); dualistička religija, izvorno izvankršćanski fenomen koji 'strogo govoreći nema vlastitu tradiciju', ali parazitski hrani sve glavne vjerske struje u helenističkim i rimskim razdobljima (K. RUDOLPH, Gnosis. The nature and history of Gnosticism, San Francisco, 1983.) « (Zlatko PLEŠE, Gnostic literature, u: R. HIRSCH-LUIPOLD, H. GÖRGEMANNS, M. von ALBRECHT (ur.), Religiöse philosophie und philosophische Religion 
Peter M. Burfeind u uvodu u svoju knjigu »Gnostic America«, govoreći o novoj religioznosti društva i američke nacije, ističe da je gnosticizam u blizini riječi »autentičan«. Naime,

»riječ autentičan potječe od današnje standardne pop filozofije - egzistencijalizma. U najpotpunijem smislu svojih paradoksalnih termina, egzistencijalizam je religija ateista. Autentičnost ili stvaranje vlastitog 'Ja' je njezina glavna pobožnost. Izbor je njezin sakrament. Tako se događa stvaranje Ja.. ${ }^{8}$

Gnosticizam privlači one koji tragaju za neograničenom, nepokvarenom duhovnošću, onom »outside the box« naspram »starih« načina razmišljanja. Briše granice između različitih bića, ruši zidove unutar kojih je nešto određeno, zamagljuje granice.

Isti autor primjećuje da suvremeni gnosticizam sam u sebi nije denominiran, već poziva na jedinstvo za koje tvrdi da nadilazi sve ono što je denominirano, bilo da je riječ o učenjima crkvenog tijela ili takozvanim »rodnim konstrukcijama . ${ }^{9}$ Tu dolazimo do pape Franje i njegovog poimanja termina (neo)gnosticizam i (neo)pelagijanizam.

\section{Klasično poimanje pojmova gnosticizam i pelagijanizam}

\subsection{Gnosticizam}

Grčka riječ gnôsis ( $\gamma v \hat{\omega} \sigma ı \varsigma)$ opisuje i označava znanje općenito. Stari su Grci razlikovali znanstveno ili reflektivno znanje (netko poznaje materiju - predmet!) od znanja koje je stečeno promatranjem ili iskustvom (netko me poznaje!). Gnostičko znanje mogli bismo prevesti pojmom uvid, jer gnoza uključuje intuitivni proces spoznaje samoga sebe i svojega porijekla. ${ }^{10}$

U rječnicima filozofskih pojmova pod natuknicom gnoza, primjerice, spominje se da

"pojam ne označuje samo spoznaju kao umnu sposobnost, nego dobiva religiozno značenje spoznaje po kojoj se pojedinac spašava. Pojmom gnoza označavan je poseban oblik spoznaje božanskih tajni, pridržan za povlašten sloj 'izabranih'.,"11

Problem pojma gnôsis ne nalazimo samo u kasnim antičkim spisima i idejama koje mi danas označujemo terminom gnosticizam, već i kod ranokršćanskih

der frühen Kaiserzeit, Tübingen, Mohr Siebeck, 2009, 163). Sličan tekst se nalazi i kod Ries, Gli gnostici..., 15.

${ }^{8}$ Usp. Peter M. BURFEIND, Gnostic America, Toledo - Ohio, Pax Domini Press, 2014, e-book, 12.

${ }^{9}$ Usp. isto, 30.

${ }^{10}$ Usp. Elaine PAGELS, Gnostička jevandelja, Beograd, Pečat, 1981, 23.

${ }^{11}$ Anto MIŠIĆ, Rječnik filozofskih pojmova, Split, Verbum, 2000, 104. 
pisaca u raznim oblicima. Neki njime opisuju znanje i spoznaju, dok ga drugi koriste za opise heretika i protivnika crkvenoga nauka. Klement Aleksandrijski same kršćane naziva »jedinim pravim gnosticima ${ }^{12}{ }^{12}$ dok Justin, Irenej i ostali termin gnosticizam koriste za obilježavanje protivnika crkvene nauke.

Gnosis susrećemo i u filozofiji, u hermetizmu, kao i u hermetičkim sustavima misli. ${ }^{13}$ No, ni tu znanstvenici nisu složni oko značenja termina i njegove uporabe. Neki smatraju da bi se njime mogle opisati religijske prakse i sustavi koji su drukčiji od tradicionalnog kršćanstva i judaizma, usprkos činjenici da iz njih proizlaze. Drugi pak smatraju da je riječ o drukčijem razvoju misli koji proizlazi iz poganskih i staroegipatskih kultura koje prethode kršćanstvu, a proširio se u vremenu Rimskoga Carstva. ${ }^{14}$

Gnosis ima mnoštvo škola, sljedbi, varijanti i mitova, pa ih je gotovo nemoguće sve staviti pod isti terminološki naziv i sustav. Tako ni terminom gnosticizam nije moguće obuhvatiti sve religijske pokrete, značenja i njihove interpretacije. U tom se duhu može reći da mnoge vrste gnoze, tj. traženja znanja postoje i danas. Primjećuje ih se u recentnim filmovima, literaturi, znanosti, a posebice u scijentizmu i u tzv. STEM području koje danas doživljava svoju renesansu. Ritualna gnoza, tj. prakticiranje gnosticizma kao vjere, nije nestalo s osudom Katoličke crkve u ranim stoljećima, već se transformiralo kroz stoljeća i održavalo u raznim oblicima. Najprominentniji primjer je maniheizam koji se u pojedinim državama održao sve do 14. stoljeća. Verzija »klasičnog« gnosticizma je doživjela svoj procvat u Italiji i Francuskoj tijekom 15. i 16. stoljeća, te i danas ima svoje biskupe, crkve i svećenike.

\subsection{Pelagijanizam}

Pelagijanizam kao termin potječe od monaha Pelagija (390-418) koji je tvrdio da istočni grijeh ne utječe na pojedinca zbog njegove slobodne volje, te je zbog toga bio osuđen od sv. Augustina i drugih predstavnika Crkve na saboru u

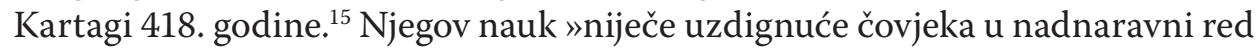
i niječe istočni grijeh. Prema Pelagiju, Adamov grijeh utječe na njegove potomke samo putem lošeg primjera. ${ }^{16}$

\footnotetext{
${ }^{12}$ Usp. Claudio MORESCHINI, Povijest patrističke filozofije, Zagreb, Kršćanska sadašnjost, 2009, 109.

${ }^{13}$ Usp. Antti MARJANEN, Gnosticism, u: Susan Ashbrook HARVEY, David G HUNTER (ur.), The Oxford handbook of early Christian studies, Oxford, Oxford University Press, 2010, 206.

${ }^{14}$ Usp. isto.

${ }^{15}$ Usp. Mathijs LAMBERIGTS, Pelagius and Pelagians, u: Susan Ashbrook HARVEY; David G. HUNTER (ur.), The Oxford handbook of early Christian studies, Oxford, Oxford University Press, 2010, 258-260.

${ }^{16}$ Ludwig OTT, Fundamentals of Catholic Dogma, Rockford, Tan Books and Publishers, 1974, 222-223.
} 
Izvorna milost koju se susreće u Svetom pismu nije toliko važna za moralno savršenstvo osobe koliko je zapravo sam čovjek (osoba) taj koji svojim snagama, naporima i silama može doći do tog savršenstva. Drugim riječima, milost se može postići svojim vlastitim naravnim nastojanjima. Uz pomoć svoje slobodne volje čovjek može živjeti bezgrešan i svet život. Prema tome, čovjekova potreba za milošću Božjom je samo izvanjska, a po samim dobrim djelima čovjek može postići spasenje. ${ }^{17}$ Tako se u pelagijanizmu gubi bilo kakva potreba za drugim - bilo čovjekom, bilo Bogom.

\section{Gnosticizam i neopelagijanizam u pobudnici pape Franje Gaudete et exsultate (35-62)}

Iako je u svojoj pobudnici Gaudete et exsultate ${ }^{18}$ pojmovima gnosticizam i neopelagijanizam papa Franjo posvetio čitavo drugo poglavlje, prvi put ih spominje u Evangelii gaudium: ${ }^{19}$

»Jedna je privlačnost gnosticizma čisto subjektivna vjera koju jedino zanima određeno iskustvo ili niz ideja i spoznaja za koje se drži da mogu utješiti i prosvijetliti, ali gdje se pojedinac u konačnici ostavi zatvoren u skučenom okviru vlastitog razuma i svojih osjećaja. Drugi je autoreferencijalni i prometejski neopelagijanizam onih koji se u konačnici uzdaju samo u vlastite snage i smatraju se većima od drugih jer se pridržavaju određenih pravila ili zato što su nepokolebljivo vjerni određenom katoličkom stilu iz nekih prošlih vremena. To je tobožnja doktrinarna ili disciplinarna postojanost koja vodi do narcisoidnog i autoritarnog elitizma, gdje se druge, umjesto da im se naviješta evanđelje, analizira i klasificira, i umjesto da se olakšava pristup milosti, snage se troše na nadzor i provjeru. I u jednom i u drugom slučaju ne pokazuje se stvarno zanimanje ni za Isusa Krista ni za druge. To su očitovanja antropocentričnog imanentizma. Nije moguće zamisliti da ti skučeni iskrivljeni oblici kršćanstva mogu uroditi autentičnom evangelizacijskom poletnošću« (EG 94).

Premda je na prvi pogled riječ samo o dvama pojmovima, gnosticizam i neopelagijanizam u samom tekstu EG, važno je zapaziti pojmove prometejski i autoreferencijalni koje papa Franjo veže uz pojam neopelagijanizam, te pojmove narcisoidan i elitistički koji su vezani uz oba pojma. Rezultat ili posljedica ovakvih stavova je, prema Papinim riječima, antropocentrični imamentizam. O čemu je tu zapravo riječ?

\footnotetext{
${ }^{17}$ Usp. Placuit Deo, 3, bilj. 9.

${ }^{18}$ Papa FRANJO, Gaudete et exsultate - Radujte se i kličite (9.IV.2018), Zagreb, Kršćanska sadašnjosti, 2019, dalje: GE.

${ }^{19}$ Papa FRANJO, Evangelii gaudium - Radost evanđelja (24.XII.2013), Zagreb, Kršćanska sadašnjost, 2015, dalje: EG.
} 
Moguće da su ovom načinu razmišljanja i osjećanja stava Crkve pridonijele i misli pape Benedikta XVI. koje je papa Franjo iznio u EG 83, gdje najveću prijetnju kršćaninu i osobi vidi kao »bezlični pragmatizam svakodnevnog života Crkve, u kojem sve naizgled teče uobičajenim tijekom, a zapravo vjera sve više slabi i zapada u sve jadnije stanje«. Papa tu nastavlja u pomalo pesimističnom tonu:

»Razvija se psihologija groba, koja malo-pomalo pretvara kršćane u mumije iz muzeja. Razočarani stvarnošću, Crkvom ili sami sobom, žive u stalnoj napasti da se prepuste sladunjavoj melankoliji, beznađu, što obuzima srce kao 'najdragocjeniji eliksir zloduha'« (EG 83).

Nisu li upravo pragmatizam i melankolija izvor antropocentričnog imanentizma? Ili je možda problem u modernizmu kojeg je već papa Pio X. nazvao »sintezom svih hereza«? $?^{20} \mathrm{U}$ pobudnici GE papa Franjo pojmove gnosticizam i neopelagijanizam prepoznaje kao zapreke na putu prema svetosti. Riječ je zapravo o ostvarenju imanentizma i pogrešnog pragmatizma, kao i nedovoljne autentičnosti te pretjeranog antropocentrizma.

U pojmu gnosticizma papa Franjo izražava problem otuđenja čovjeka u njegovoj potrebi i želji da se suoči s transcendentnim, tj. potpuni nedostatak transcendentnog i kozmičkog u njegovu svagdanjem životu. Upravo kroz tu transcendenciju, naviješta se i čovjekova potreba za spasenjem, a kroz prizmu eshatologije, soteriologije i globalnog spasenja, papa Franjo vidi i problem neopelagijanizama u koji moderni čovjek sve više upada. Novi pobornici gnosticizma, tako ih Papa imenuje, prihvaćaju nauk Crkve, no bez njezinih misterija i hijerarhije, »Boga bez Krista, Krista bez Crkve i Crkvu bez naroda« (GE 37).

Upravo su prvi gnostici bili ti koji su težili za znanjem, te tvrdili da će ih upravo znanje spasiti. Iščitavali su drukčije znakove i prepoznavali svoje uzore u tekstovima koje danas nazivamo kanonskima. Papa Franjo tu utrku za znanjem primjećuje u modernom svijet u kojem živimo, nagovješćujući i podsjećajući da je važan i onaj čovjek, pojedinac, koji je tu pokraj mene. Gnosticizam za Papu podrazumijeva:

»vjeru zatvorenu u subjektivizam, kojega zanima samo određeno iskustvo ili niz razmišljanja i spoznaja koji se smatraju da tješe i prosvjetljuju, no, gdje u konačnici osoba ostaje zatvorena u vlastitom razumu ili u svojim osjećajima« (GE 36). ${ }^{21}$

Ono što danas često privlači gnosticizmu je stanovita ravnoteža koja je formalna i pretpostavlja čistoću nauka (GE 38). Svaki sustav koji promatramo samo površno, djeluje nam privlačno i strukturirano. Posebice religije koje daju odgovore na ključna pitanja čovječanstva bez mnogo truda i napora. Upravo u toj iluzornoj privlačnosti gnosticizma, papa Franjo prepoznaje probleme da-

\footnotetext{
${ }^{20}$ PIO X., Pascendi Dominici Gregis, 8.IX.1907. (DH 3475-3500).

${ }^{21}$ Usp. i EG 94.
} 
našnjega društva i današnjega čovjeka, tj. već prije spomenuti egzistencijalizam i pop kulturu. Uviđa da čovječanstvo teži prema znanju i prema vjeri a koja je u svojoj biti i naravi površna. Traži se informacija, a ne i znanje kao takvo. Moglo bi se reći da gnosticizam daje odgovore na sve probleme, bilo da je riječ o patnji, o siromaštvu, bilo da je riječ o nečemu sasvim nevažnom. Čovjek će se prije zadovoljiti novim odgovorima koje će primiti od gnosticizma, tarota, astrologije ili nekog drugog načina »objave« negoli te iste odgovore potražiti u vlastitoj religiji. Papa drži da ni Crkva više nije izuzeta od tih tendencija. Istodobno, ona nije njihov (epi)centar, nego dio koji je također zahvaćen gnosticizmom i ostalim strujanjima koja su u učiteljstvu Crkve posljednjih stoljeća smatrana izvanjskima.

Problem s kojim se gotovo svaki pojedinac danas suočava, bilo da je riječ o vjerniku ili nevjerniku, jest nedostatak osobne komunikacije s drugima, dragovoljno odustajanje od vlastitoga ega i vlastitih stavova u koje zapada sve dublje upravo tražeći svjetlo, ne u transcendenciji, nego u samom sebi. Ako čovjek gleda samo na sebe, nakon nekog vremena ne samo da neće vidjeti druge ljude, nego će sam sebi postati dostatan za sve, uključujući i vlastito spasenje. U tom kontekstu Papa promatra gnosticizam, nazivajući ga jednom od najgorih ideologija. Naime, gnosticizam neopravdano uzdiže spoznaju ili neko drugo iskustvo u nezamislive visine, istodobno drži da je upravo to vlastito viđenje stvarnosti savršenstvo i transcendencija koje čovjek traži (GE 40). Samim time, on je okamenjen u apstrakciji (GE 37). Gnosticizam se često predstavlja kao nešto što je odvojeno od ove stvarnosti koju živimo ili kao nešto što posjeduje vlastitu stvarnost koja je često »upakirana« u posebnu duhovnost ili čak pobožnost.

U gnostičkim naukama i mitovima puno toga se odvija na površini, tako da ni ljudski um nije ni u biti dirnut niti zahvaćen (GE 38). Upravo iz tog razloga mnogi posežu za gnosticizmom kao nadomjestkom za vlastitu pobožnost ili religioznost. Ključno je u ovim razmišljanjima da nije riječ samo o pojedincima koji su izvan Crkve ili su je napustili, nego i o samim vjernicima, osobama posvećenoga života pa i svećenicima, redovnicima i biskupima.

Još više od ideologije, ezoterije i sustava misli, papa Franjo spominje da nitko osim Boga ne može dati odgovore na sva pitanja, te da onaj tko želi da mu je sve jasno i sigurno, taj sam želi vladati Božjom transcendencijom. Nismo mi ti koji možemo Boga nadići, već je On taj koji nas neizmjerno nadilazi, uvijek nas iznenađuje, te postavlja vrijeme, mjesto i uvjete susreta (GE 41). Čak i više od toga, bez obzira je li riječ o osobi koja je okružena blagostanjem i sređenim odnosima ili pak porocima, Bog je prisutan u životu svake osobe. Upravo ta činjenica, kao i poziv iz evanđelja, nadahnjuju nas da tražimo Boga u svim ljudima, u svim ljudskim životima. To traženje odražava sastavni dio otajstva kojeg gnostički mentalitet odbacuje jer ga ne može kontrolirati (GE 42). 
U nizu previranja ljudskih života, kao alternativu papa Franjo nudi i poziva na jednostavnost evanđelja. Takav nam poziv, posebice u kršćanstvu, može djelovati zbunjujuće, zastarjelo i pomalo nedorečeno. Jedna od velikih opasnosti je vjerovanje da smo već sveti, da smo savršeni, da smo bolji od »neuke« mase ili pak bolji od onog drugog tko je kraj nas i do nas samo zato jer nešto više znamo o životu Crkve (GE 45). U ovim redcima i brojevima (GE 43-46) itekako se ističe opasnost od antropocentričnog imanentizma gnosticizma i gnoze opisanog u EG gdje je pojedinac, kao ja i jedinka, jedino i konačno mjerilo svih stvari. Potrebna je poniznost, vjera u utjelovljenje i sama teologija u svojoj izvornosti

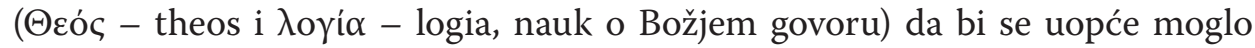
govoriti o svetosti. S druge pak strane, upravo o svetosti treba govoriti kao o nečemu stvarnom i ostvarivom.

Druga velika zapreka na putu prema svetosti za papu Franju je pelagijanizam. Papa ističe da su mnogi počeli shvaćati da spoznaja, intelekt i gnoza nisu sredstva kojima se čovjek mijenja nabolje i postaje svet, nego da čovjeku mjerilom na putu prema svetosti postaje njegov život. Drugim riječima, da se vlastitim naporima i iskustvima drugima pokazuje kao da je svet i neporočan te da vlastitim naporima može doći do postignuća koja su gnostici pripisivali razumu i intelektualnoj sposobnosti odabranih (GE 47-48). Ta se moć očituje u pojedincu koji se smatra boljim od drugih, vjernijim, odanijim, katoličkijim, pobožnijim... U njegovim obraćanjima onima koje smatra da su manje pobožni ili manje vjerni (vrijedni) od njega, u svom govoru i isticanju da je uz Božju milost sve moguće, papa Franjo primjećuje da ta osoba misli da je sve moguće samo ljudskom voljom na koju se poslije »lijepe« atributi Božje milosti (GE 49).

Pelagijanski mentalitet papa Franjo vidi u slatkorječivu govoru o Božjoj milosti u onih ljudi koji se osjećaju superiornima nad drugima jer održavaju crkvene norme ili su nepomično vjerno odani katoličkom stilu i nauku (GE 49). ${ }^{22}$ $\mathrm{Za}$ Papu je milost povezana s iskrenim priznanjem, s patnjom i s molitvom. Milost pretpostavlja narav te zahtijeva da se na nju oslanjamo. Crkva je mnogo puta učila da kršćani nisu opravdani svojim djelima ili svojim naporima, nego da je riječ o daru i milosti Božjoj. Ponovno ističe da je opasnost pelagijanizma u činjenici da se često zaboravlja da kao kršćani prebivamo u Bogu, te da on dopušta da živimo u njegovu svjetlu i njegovoj ljubavi (GE 51-52).

Osim pelagijanizama često se zaboravlja i na učiteljstvo Crkve koje govori o milosti, ne samo u suprotstavljanju Lutherovu sola gratia, nego i na sinodama, koncilima, kao i u Katekizmu Katoličke crkve. Svi se oni bave temom milosti Božje (GE 52-55). Upravo po milosti, a ne po zaslugama za vlastite dijela, papa Franjo spominje svece koji se nisu pouzdavali u svoja vlastita dijela, točnije nisu u njih stavljali svoju nadu. Tu on navodi citat sv. Terezije od Djeteta Isusa koji završava riječima: »Svaka je naša pravednost nesavršena u tvojim očima« (GE 54). Ovo upozorenje na zaboravljeno učiteljstvo Crkve Papa u broju 56.

\footnotetext{
${ }^{22}$ Usp. i EG 94.
} 
zaokružuje interpretacijom poznate molitve sv. Ignacija Lojolskoga Suscipe ${ }^{23} \mathrm{~s}$ napomenom da tek na temelju Božjega dara možemo slobodno i ponizno primiti njegovu milost i dopustiti joj da nas preobrazi, stavljajući u nju sve naše sile, napore i borbe.

Protivljenje daru i milosti Božjoj, papa Franjo vidi u različitim stavovima među ljudima, poput opsjednutosti zakonom, težnje da se postignu društvene i političke pobjede, u njegovanju liturgije, crkvenoga nauka i prvenstva Crkve, samohvale... i mnogim drugim praksama i postignućima vlastitih snaga (GE 57). Papa ujedno ističe da mnogi kršćani upravo u tim stvarima troše svoju snagu, svoje vrijeme i energiju, umjesto da se prepuste ljepoti i radosti evanđelja te da ga sa žarom i radošću navješćuju drugima (GE 57). ${ }^{24}$ Nastavlja,

»to se događa kada neke kršćanske grupe pridaju preveliku pozornost vršenju određenih vlastitih normi, običaja ili stilova. Na taj se način Evanđelje često zanemaruje, oduzimajući mu njegovu očaravajuću jednostavnost i njegov okus. Možda se tu radi o istančanom obliku pelagijanizma, jer, čini se, da se time život milosti podčinjava određenim ljudski tvorevinama« (GE 58).

Jednako tako papa Franjo upozorava na opasnost kojoj se izlažu skupine, pokreti i zajednice koje započinju intenzivnim životom u Duhu, a kasnije upravo zbog težnje prema izvanjskoj formi skončaju u razilaženju, u određenim arhaizmima ili u svojim vlastitim sistemima koji su daleko od života Crkve.

Slično papa Franjo upozorava na zatvorenost današnjeg čovjeka pred drugima (EG 78). Spominje opasnost od toga da se duhovni život poistovjećuje s nekim pobožnim vježbama koje pružaju odličnu utjehu, ali istodobno stvara opasnost da čovjek svoje poslove doživljava kao puki privjesak vlastitoga života. Drugim riječima, Papa ovdje ističe da čovjek može vrlo lako ograničiti posao kao nešto izvanjsko, a ne doživljavati ga iznutra, kao nešto njemu vlastito, kao nešto što je iskonski i istinski njegovo. Upravo u tome papa Franjo prepoznaje individualizam, krizu identiteta i nedostatak gorljivosti. Ta tri zla po njemu započinju praktični relativizam koji se ogleda u djelovanju kao da Boga nema, kao da ne postoji; u odlučivanju kao da siromaha uopće nema; u postavljanju vlastitih ciljeva kao da drugi ne postoje; u djelovanju kao da oni koji nisu primili navještaj uopće ne postoje (EG 80). Nažalost, to se prepoznaje i u Crkvi.

Papa upozorava da je u posljednjih nekoliko desetljeća u katoličkom narodu došlo do raskida u prenošenju kršćanske vjere s jednog naraštaja na drugi. Često se nalaze zamjene u izvanjskim izrazima (slavljenjima) i tradicijama pojedinih skupina i izjednačava ih se s pučkim pobožnostima, a one to zapravo nisu (GE 70).

\footnotetext{
${ }^{23}$ Molitva sv. Ignacija koja započinje riječima: Uzmi, Gospodine, i primi... (Suscipe, Domine...), usp. Ignacije LOJOLSKI, Duhovne vježbe, Zagreb, Filozofsko-teološki institut Družbe Isusove, ${ }^{3} 2003,66$, br. 234.

${ }^{24}$ Usp. EG 95.
} 
Kao svjetlo na našem vjerničkom putu i smjernice za život danas bi nam trebale biti teološke kreposti kojima je cilj i svrha Bog. Na tom putu prema svetosti, nastavlja papa Franjo, može nam itekako pomoći ako uspijemo prepoznati obrise Božjeg lica u drugima. To se Božje lice napose ističe u onim najmanjim, najviše ranjenima, nezaštićenima i najpotrebnijima jer upravo $u$ njima, u tim ostacima ranjivoga čovjeka, Gospodin će na kraju vremena oblikovati svoje posljednje »umjetničko djelo« (GE 61). Kršćanski ideal pojedinca uvijek poziva na nadilaženje sumnji, tajnog nepovjerenja, straha da će izgubiti svoju privatnost, obrambenih stavova koje nameće današnji svijet... Evanđelje čovjeka uvijek poziva da se upusti u rizik susreta s licem drugoga, s njegovom osobom. To danas postaje poseban izazov!

\section{Zaključak}

Papino razmišljanje o gnosticizmu i pelagijaniznu ne prati konvencionalne i standardne izričaje niti zaključke, no možda je upravo zato potrebno čuti i vidjeti što on želi reći i postići. Kada je prvi put spomenuo te pojmove u pobudnici Evangelii gaudium obogatio ih je epitetima kao što su prometejski, autoreferencijalni i drugima. Njihovo se potanko tumačenje nalazi u drugom poglavlju pobudnice Gaudete et exsultate.

Konfuzija koju pobudnica izaziva očituje se u činjenici da su vjernicima, posebice kršćanima, svi ti pojmovi jasni i točno omeđeni kad se o njima govori na tribinama, u predavanjima i na katehetskim poukama. Poteškoća nastaje $u$ modernom svijetu koji vrvi informacijama sa svih strana, te je time pojedinac pomalo »osuđen « na gnosticizam u onom smislu kako ga definira papa Franjo, a glasi: Traži samo ono površno!

Moguće je da termini gnosticizam i pelagijanizam prvotno zbunjuju, možda upravo zato što većina vjernika, zajedno s crkvenom hijerarhijom, smatra da su oni već nadiđeni, te da ne pripadaju Crkvi i vjeri. Točnije, do pobudnica EG i GE pape Franje ti termini nisu bili smatrani kao nešto što zahvaća Crkvu niti to da su dio života Crkve.

Možda se uistinu u gnostičkim mitovima i današnji čovjek pronalazi kao onaj koji je odbačen, prezren, te koji nikada nije u mogućnosti dokraja spoznati ono što je iznad njega - bilo da je riječ o transcendentnom ili ovozemnom. Gnosticizam uvijek nudi drukčiji put: avanturu, putovanje, način približavanja, način života koji nadilazi »stare paradigme« vjere i razuma. Time je on vrlo opasan i za religiju u 21. stoljeću ako ga se podcijeni, bilo da je riječ o klasičnom gnosticizmu, bilo o »skučenoj osobnosti« o kojoj govori papa Franjo. Činjenica je da se od 5. stoljeća u Crkvi termini gnosticizam i pelagijanizam nisu koristili, te da se nakon Drugoga vatikanskog sabora smatra da je Katolička crkva otvorena svijetu, da se na nju gleda zasebno, a na svijet kao na nešto odvojeno. 
Gnosticizam i pelagijanizam nikada zapravo nisu nestali, nego su se u povijesti pojavljivali u različitim oblicima. Većina tih pojavnosti je prepoznatljiva i danas u raznim ezoterijama, tarotima, teozofijama, pa i u samim prirodoslovnih i humanističkim znanostima. Često se tim formama i fenomenima daje i pridjev "neo" da bi ih se moderniziralo. $U$ najnovije vrije počeo se rabiti i pridjev »cyber«. Ostaje samo pitanje vremena kada će doći do cyber-gnoze i cyber-pelagijanizma. U stanovitom smislu, »cybergnozu« smo već upoznali $u$ filmskoj umjetnosti, primjerice, u filmu »Matrix« - samo još nema dovoljno temelja da je se tako nazove. Kako god da se fenomen zvao, u svojem korijenu i gnoseologiji uvijek u centru kozmosa stoji čovjek koji pokušava naći put do davno izgubljenoga znanja, te pri tome u većini slučajeva gubi sam sebe prolazeći kroz de-evoluciju svojih zatrovanih i zatvorenih ideja. U tomu i jest imanentni antropocentrizam na koji je papa Franjo upozorio.

\section{Mikolaj Martinjak* \\ Gnosticism and Neopelagianism - an Obstacle to Holiness or a Source of Confusion? \\ Summary}

The terms »Gnosticism« and »Pelagianism« are known to theologians, historians, religious scholars, philosophers, and other scholars of the humanities. As individual terms we may hear them from time to time in colloquial speech, especially the derivative "agnosticism" or "agnostic«. Until the apostolic exhortations of Pope Francis, these two nominations were related to Church heresies from the beginning of the Church teachings. The article, in the historical context of this heresy, places the Pope's speech on Gnosticism and Pelagianism, which he begins in his apostolic exhortation »Evangelii Gaudium» and extends it in the apostolic exhortation »Gaudete et exsultate«. After a brief account of the classical use of these terms and the problems associated with them, as well as the pope's interpretation of these terms, the article answers the question of whether these terms are truly a »barrier« to the path of holiness or a source of confusion.

Key words: Christian Anthropology, Church Heresies, Evangelii Gaudium, Gaudete et exsultate, Gnosticism, Pelagianism, Pope Francis.

\footnotetext{
* M. Sc. Mikolaj Martinjak, PhD candidate, University of Zagreb, Faculty of Philosophy and Religious Studies; Address: Jordanovac 110, HR-10000 Zagreb, Croatia; E-mail: mika@ffrz.hr.
} 